\title{
Estimates of Climate Change Impact on River Discharge in Japan Based on a Super-High-Resolution Climate Model
}

\author{
Yoshinobu Sato*, Toshiharu Kojiri, Yuri Michihiro, Yasushi Suzuki, and Eiichi Nakakita \\ Disaster Prevention Research Institute, Kyoto University, Kyoto, Japan
}

Received 5 October 2011, accepted 3 May 2012

\begin{abstract}
ABSRTRACT
The impact of climate change on river discharge was assessed by hydrological simulations for several major river basins in Japan using the latest version of a super-high-resolution atmospheric general circulation model (AGCM) with a horizontal resolution of about $20 \mathrm{~km}$. Projections were made using two different datasets, one representing the present climate (1980 1999) and the other representing the end of the $21^{\text {st }}$ century (2080 - 2099) assuming the SRES A1B scenario. River discharge was estimated by a distributed hydrological model calibrated against observed river discharge in advance. The results showed that even if the amount of precipitation does not change much in the future, river discharge will change significantly because of the increase in rainfall, decrease in snowmelt, and increase in evapotranspiration with higher air temperature. The impact of climate change on river discharge will be more significant in the northern part of Japan, especially in the Tohoku and Hokuriku regions. In these regions, the monthly average river discharge at the end of the $21^{\text {st }}$ century was projected to be more than 200\% higher in February and approximately 50 - 60\% lower in May compared with the present flow. These results imply that the increase in air temperature has important consequences for the hydrological cycle, particularly in regions where the water supply is currently dominated by snowmelt.
\end{abstract}

Key words: Climate change, River discharge, AGCM, Distributed hydrological model

Citation: Sato, Y., T. Kojiri, Y. Michihiro, Y. Suzuki, and E. Nakakita, 2012: Estimates of climate change impact on river discharge in Japan based on a super-high-resolution climate model. Terr. Atmos. Ocean. Sci., 23, 527-540, doi: 10.3319/TAO.2012.05.03.02(WMH)

\section{INTRODUCTION}

With increasing concern over global warming, the hydrological impact of climate change has attracted considerable attention. Increases in surface temperature will have important consequences for the hydrological cycle, particularly in regions where the water supply is dominated by melting snow or ice (Barnett et al. 2005). The disappearance of permafrost layers, glacial recessions, and changes in snowmelt will also have severe effects on the water cycle in cold regions (Qiu 2008). For example, Hara et al. (2008) reported that the snow depth in the northern part of Japan decreased by $40 \%$ under the warmer conditions projected for the 2070s in a pseudo-global-warming experiment.

In recent years, general circulation models (GCMs) based on the physical principles of fluid dynamics and heat and radiation transfers have become the most reliable tools

\footnotetext{
* Corresponding author

E-mail: satou.yoshinobu.3e@kyoto-u.ac.jp
}

for projecting future climate. Using GCMs, the changes in various hydro-meteorological parameters such as air temperature, precipitation, and evapotranspiration are projected more clearly on global scales. According to multi-model ensemble analysis, river runoff is projected to increase at high latitudes in North America, Eurasia, and central Africa. However, river runoff is projected to decrease in southern Europe, the Middle East, the mid-latitudes of North America, and southern Africa (Milly et al. 2005; Nohara et al. 2006). Furthermore, extreme events such as severe floods are projected to increase by the end of the $21^{\text {st }}$ century with global warming (Milly et al. 2002). However, the spatial resolution of typical GCMs (approximately $100-400 \mathrm{~km}$ ) is too coarse to predict major hydrological and convective processes that occur on sub-grid scales. Thus most available GCMs are only suitable for predicting the hydrological impact of climate change on relatively large watershed or continental scales (i.e., Vörösmarty et al. 2000; Hirabayashi et al. 2008). 
To address this problem, a super-high-resolution global atmospheric general circulation model (AGCM) with 20-km horizontal resolution was developed by the Meteorological Research Institute (MRI) of the Japan Meteorological Agency (JMA) to project changes in future weather extremes under global warming (Mizuta et al. 2006; Kitoh et al. 2009). The super-high-resolution model can reproduce actual climate conditions more accurately than lower resolution models (Kitoh et al. 2008; Kusunoki et al. 2011). Wada et al. (2008) used the MRI-AGCM to conduct a statistical analysis of precipitation probability and to assess flood risk in Japan. They showed that the magnitude of the 100 -year occurrence probability of annual maximum precipitation will increase by more than $40 \%$ in the northern part of Japan. However, to develop appropriate policy measures for practical flood control and water resources management, considering the influence of climate change on river discharge, runoff simulations must be conducted for specific river basins on regional scales.

This study investigated the impact of climate change on river discharge in several major river basins in Japan by conducting distributed hydrological simulations using the latest version of the MRI-AGCM.

\section{METHODS}

\subsection{Hydrological Model}

The Hydrological River Basin Environment Assessment Model (Hydro-BEAM) developed by Kojiri (2006) was used for the hydrological simulation. The model was a cell-concentrate-type distributed hydrological model that divided each grid cell into two pairs of rectangular hill slopes and one river channel. Spatial resolution of $1 \mathrm{~km}$ and a 10-minute time step were applied in this study. The surface flow and subsurface flow from the upper soil layer and channel flow were calculated using a kinematic wave model. The base flow from the lower soil layer was calculated by a multi-layer linear storage function model. Deeper seepage and long-term groundwater storage were not considered in this analysis. All of the input data for Hydro-BEAM were interpolated to $1-\mathrm{km}$ grid mesh data using the inverse distance-weighting (IDW) method.

We used the following kinematic wave equation for open channel flow:

$$
\begin{aligned}
& \frac{\partial A}{\partial t}+\frac{\partial Q}{\partial x}=q i n \\
& Q=\alpha A^{\frac{4}{3}} \\
& \alpha=\frac{\sqrt{s l}}{n}\left[\frac{m}{\left(2 \sqrt{1+m^{2}}\right)^{2}}\right]^{\frac{1}{3}}
\end{aligned}
$$

where $A$ is the flow cross-sectional area $\left(\mathrm{m}^{2}\right), Q$ is the flow discharge $\left(\mathrm{m}^{3} \mathrm{~s}^{-1}\right)$, qin is the lateral inflow discharge per unit length $\left(\mathrm{m}^{2} \mathrm{~s}^{-1}\right), \alpha$ is a constant of Manning's equation, $s l$ is the channel slope, $n$ is Manning's friction coefficient (equivalent roughness), and $m$ is the slope of the river bank. The $m$ in mesh ' $i$ ' is defined as

$m i=\frac{B i}{H i}$

where $B i$ is the channel width (m) of each mesh and $H i$ is the depth of the water $(\mathrm{m})$. These variables were obtained at reference points in each river basin. Equation (1) represents the continuity equation and is derived from the mass conservation principle. Equation (2) is derived from Manning's law assuming the flow resistance of open channel uniform flow. A catchment (one grid cell) is modelled as a set of hill slopes. Runoff flow from these slopes is modelled as shallow water flow. The hydraulic radius of the shallow flow in Manning's law can be approximated by the water depth, $h(\mathrm{~m})$. Then, the discharge per unit width $q\left(\mathrm{~m}^{2} \mathrm{~s}^{-1}\right)$ can be expressed as

$q=\frac{\sqrt{h l}}{n} h^{\frac{5}{3}}$

where $h l$ is the hill slope. In Hydro-BEAM, channel and hill slopes less than 0.001 were modified to 0.001 to solve these equations continuously from the source area to river mouth.

Dividing both sides of Eq. (1) by the width of each hill slope (m), we obtained the following continuity equation for hill slope flow:

$\frac{\partial h}{\partial t}+\frac{\partial q}{\partial x}=f r$

where $r$ is the input effective rainfall intensity $\left(\mathrm{m} \mathrm{s}^{-1}\right)$, which corresponds to the sum of rainfall and snowmelt infiltrating into soil after extracting evapotranspiration losses, and $f$ is the direct runoff ratio, which is equal to the soil saturation ratio in the upper soil layer $(0-1)$. By integrating Manning's formula for surface flow and Darcy's formula for subsurface flow, we rewrote Eq. (5) as

$q=\alpha(h-d)^{\frac{5}{3}}+a h \quad(h>d)$

$q=a h \quad(h \leq d)$

$\alpha=\frac{\sqrt{\sin \theta}}{n}, a=K s \frac{\sin \theta}{\gamma}$ 
where $d(=\gamma D)$ is the effective soil depth of the upper soil layer (m), for which $\gamma$ is the porosity of the soil layer and $D$ is the depth of the upper soil layer (m). $\theta$ is the angle of the hill slope (radian), $a$ is a constant for Darcy's flow, and $K s$ is the saturated hydraulic conductivity $\left(\mathrm{m} \mathrm{s}^{-1}\right)$. Equation 8 is used for those cases where only subsurface flow occurs, and Eq. (7) is used for those cases where saturation excess overland flow occurs.

The kinematic wave model described above is one of the most reasonable physically-based rainfall-runoff models for flood prediction. However, it is difficult to estimate the recession discharge between the storm periods. Thus, to predict the base flow process more reasonably, a multi-layer linear storage function model was applied to Hydro-BEAM. The continuity and dynamic equations of the linear storage function model were

$$
\frac{d S}{d t}=I-O
$$

$O=k S$

where $S$ is the storage of water $(\mathrm{m}), I$ is the inflow $\left(\mathrm{m} \mathrm{s}^{-1}\right), O$ is the outflow $\left(\mathrm{m} \mathrm{s}^{-1}\right)$, and $k$ is the runoff coefficient $\left(1 \mathrm{~s}^{-1}\right)$. The fixed parameter values used for Hydro-BEAM are summarized in Table 1.

To run a distributed hydrological model, it was necessary to prepare the basin's geographical information (e.g., flow direction, channel network) in advance. First, a digital map was used to check the actual river channel network to determine the basin boundary. Actual channel network data (W15-52L, W03-07T), basin boundary (W07_52M), channel locations (W06-52M), and land-use type (L03-09M) data were obtained from the Geophysical Survey Institute (GSI) of Japan. Five land-use types (forest, grassland, urban, paddy, and water) were used to determine the land surface roughness for the Manning equation and infiltration ratio of specific land-use types. Next, the direction and connection of channels and hill slopes were determined using a $50 \mathrm{~m}$ digital elevation map (DEM) with the following assumptions: river channels run through the lowest part of each grid mesh and flow to the adjacent mesh of the steepest slope. If a depression sink occurs before the river mouth is reached, the elevation of the mesh is modified to flow down to the nearest mesh.

\subsection{SVAT Model}

To validate the performance of the hydrological model and AGCM output with the climate today, it was necessary to prepare observed meteorological datasets, such as those of total rainfall infiltration into the soil layer (net rainfall + snowmelt) and water losses from the soil layer (evapotranspiration). As shown in Fig. 1a, all of these meteorological components were included in the MRI-AGCM. However, the amounts of evapotranspiration and snowmelt are not measured directly in most routine meteorological observations in Japan. Therefore, the Soil-Vegetation-Atmosphere Transfer (SVAT) model was used to obtain unmeasured input variables for hydrological simulations from routinely observed meteorological data (Fig. 1b).

In the SVAT model, precipitation was converted to snow when the hourly air temperature was less than approximately $+2.0^{\circ} \mathrm{C}$, and snow density was set at a constant $\left(100 \mathrm{~kg} \mathrm{~m}^{-3}\right)$ to simplify the calculation. The heat balance at the land surface was calculated to estimate potential evaporation (Kondo and Xu 1997). Following Xu et al. (2005), potential evaporation $E p$ was defined as the evaporation from a continuously saturated imaginary surface. The imaginary surface had assumed surface roughness $(=0.005 \mathrm{~m})$, albedo (ref $=0.06)$, surface emissivity $\varepsilon(=0.98)$, and evaporation efficiency $\beta(=1.0)$. The surface temperature $T s$, sensible heat flux $H$, and latent heat flux $\lambda E$ were estimated from the energy balance equations

$(1-r e f) S^{\downarrow}+\varepsilon L^{\downarrow}=\varepsilon \sigma T s^{4}+H+\lambda E+G$

$H=c_{p} \rho C h U_{1}(T s-T a)$

$\lambda E=\lambda \rho \beta C h U_{1}\left[q_{s a t}(T s)-q_{a}\right]$

where $S^{\downarrow}\left(\mathrm{W} \mathrm{m}^{-2}\right)$ is the solar radiation, $L^{\downarrow}\left(\mathrm{W} \mathrm{m}^{-2}\right)$ is the downward long-wave radiation flux, and $\sigma$ is the StefanBoltzmann constant $\left(5.67 \times 10^{-8} \mathrm{~W} \mathrm{~m}^{-2} \mathrm{~K}^{-4}\right)$. The calculated surface temperature $(T s)$ was estimated to satisfy the heat balance equations presented above. The computational details for $S^{\downarrow}$ and $L^{\downarrow}$ have been described by Ma et al. (2003). When $T s$ is known, the sensible heat flux $\left(\mathrm{W} \mathrm{m}^{-2}\right)$ and latent heat flux $\left(\mathrm{W} \mathrm{m}^{-2}\right)$ are computed at the same time. In this case, $c_{p}\left(\mathrm{~J} \mathrm{~kg}^{-1} \mathrm{~K}^{-1}\right)$ is the specific heat of air, $\rho\left(\mathrm{kg} \mathrm{m}^{-3}\right)$ is the air density, $T a(\mathrm{~K})$ is the air temperature, $\lambda\left(\mathrm{J} \mathrm{kg}^{-1}\right)$ is the latent heat of vaporization, $q_{s a t}(T s)$ is the saturation specific humidity of $T s$, and $q_{a}$ is the specific humidity. $C h U_{1}\left(\mathrm{~m} \mathrm{~s}^{-1}\right)$ is the exchange speed, defined as

Table 1. Fixed parameters for the kinematic wave model.

\begin{tabular}{llc}
\hline Parameter & Value & Unit \\
\hline Saturated hydraulic conductivity $(K s)$ & 0.0001 & $\mathrm{~m} \mathrm{~s}^{-1}$ \\
Soil porosity $(\gamma)$ & 0.4 & - \\
Equivalent roughness for forest area $(n)$ & 0.7 & $\mathrm{~m}^{-1 / 3} \mathrm{~s}$ \\
Equivalent roughness for grassland $(n)$ & 0.3 & $\mathrm{~m}^{-1 / 3} \mathrm{~s}$ \\
Equivalent roughness for urban area $(n)$ & 0.03 & $\mathrm{~m}^{-1 / 3} \mathrm{~s}$ \\
Equivalent roughness for water body $(n)$ & 0.04 & $\mathrm{~m}^{-1 / 3} \mathrm{~s}$ \\
\hline
\end{tabular}


(a)



(b)

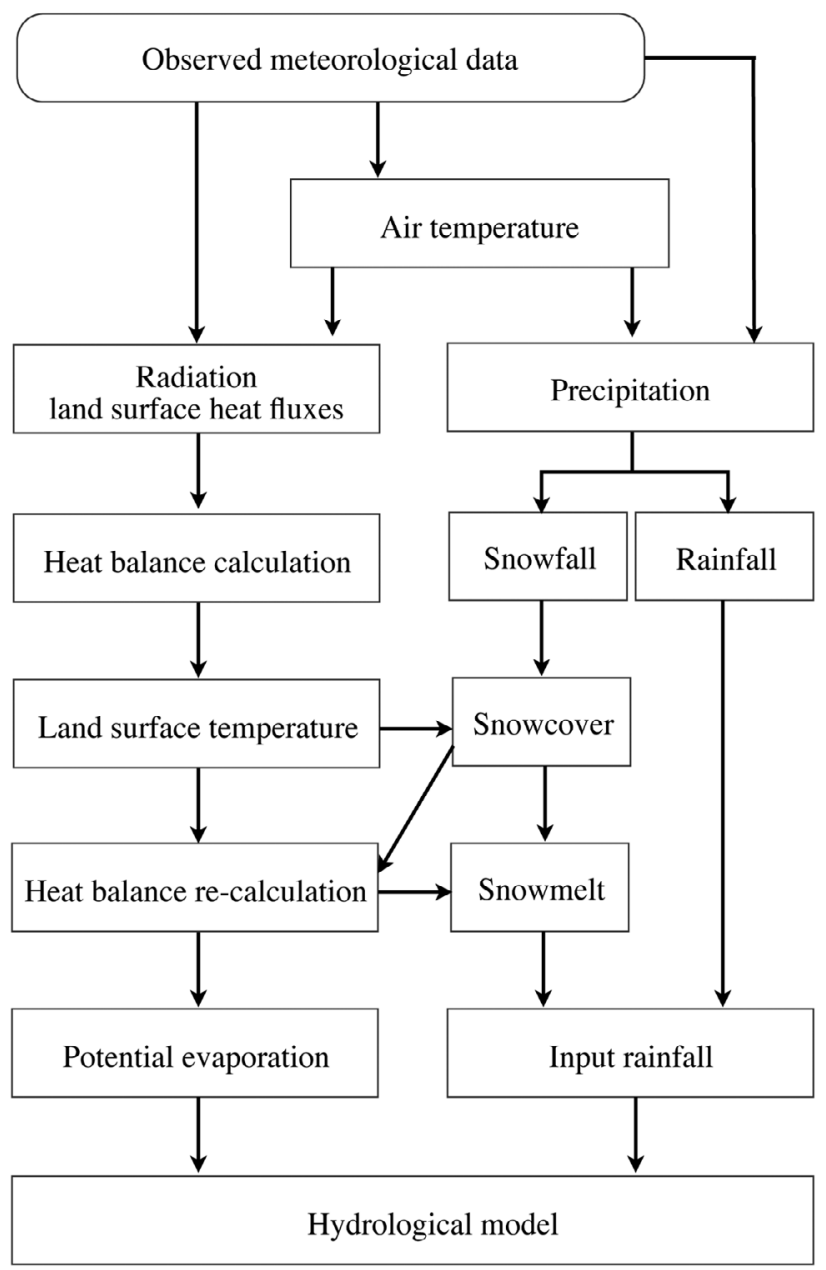

Fig. 1. Outlines to obtain input variables for hydrological model from MRI-AGCM (a) and SVAT model (b).

$$
C h U_{1}=\max \left[0.0027+0.0031 \times U_{1}, 0.0036 \times(T s-T a)^{\frac{1}{3}}\right]
$$

where $U_{1}\left(\mathrm{~m} \mathrm{~s}^{-1}\right)$ is the wind speed at $1 \mathrm{~m}$ height. The evaporation rate under these conditions was defined as the potential evaporation $E p$. The temperature of the isothermal soil layer (assumed to be the lower boundary of the SVAT model) was set at a depth of $6 \mathrm{~m}$ below the ground surface and was equal to the annual mean air temperature of each grid cell.

Soil and snow temperature profiles were calculated using the thermal conductive model developed by Outcalt et al. (1975) and Fukuda and Ishizaki (1980) to obtain the values of soil and snow heat flux, $\mathrm{G}\left(\mathrm{W} \mathrm{m}^{-2}\right)$. The soil layer and snow pack were subdivided at $0.01-\mathrm{m}$ intervals. The value of $G$ at $0.01 \mathrm{~m}$ beneath the land surface was calculated as

$\mathrm{G}=-\kappa \frac{T s-T g}{0.01}$

where $T g(\mathrm{~K})$ is the temperature at $0.01 \mathrm{~m}$ beneath the land surface, and $\kappa\left(\mathrm{W} \mathrm{m}^{-1} \mathrm{~K}^{-1}\right)$ is the thermal conductivity of soil or snow. The value of $\kappa$ was set at 2.0 for the soil layer and 0.3 for the snow layer (Table 6.9 of Kondo 1994). The amount of snowmelt was estimated using the method followed by Kondo and Yamazaki (1990).

\subsection{AGCM}

The climate model used for the experiment was the AGCM of the MRI (MRI-AGCM3.2S). MRI-AGCM3.2S is based on a model developed jointly by the JMA and the MRI (Mizuta et al. 2006). The model is the revised version of MRI-AGCM3.1S used for previous 20-km-resolution experiments (Kitoh et al. 2009). The model had a horizontal resolution of triangular truncation 959 (TL959). The transform grid was composed of $1960 \times 960$ grid cells, corresponding to approximately $20-\mathrm{km}$ grid intervals. It had 60 vertical layers (top at $0.01 \mathrm{hPa}$ ). The land surface model used was the new version of the JMA Simplified Biosphere (SiB; Ohizumi and Hosaka 2000). Vegetation, snowpack, and soil processes were coupled with the atmospheric components of the AGCM (Nakaegawa and Vergara 2010). Three simulations, assuming the present, near-future, and end of the $21^{\text {st }}$ century climate conditions were performed in the MRI-AGCM experiments. As the lower boundary conditions, observed sea-surface temperatures (SSTs) and seaice concentrations were used for the current climate simulation (1979 - 2003). For the climate simulations of the near future (2015 - 2039) and the end of the $21^{\text {st }}$ century (2075 - 2099), the SSTs projected by the Coupled Model Intercomparison Project phase 3 (CMIP3) multi-model ensemble 
(MME) dataset were used. These data were based on the A1B scenario of the Special Report on Emission Scenarios (SRES) in the Fourth Assessment Report (AR4) of the Intergovernmental Panel on Climate Change.

Among the many components of the AGCM, rainfall (precipi and $p r c s l$ ), snowmelt ( $s n 2 s l$ ), and evapotranspiration (evpsl and trnsl) were included as input variables for the hydrologic simulation (Fig. 1a). prcsl was the amount of daily precipitation reaching the soil layer after accounting for interception and transpiration losses from vegetation. $s n 2 s l$ was the amount of daily snowmelt into the soil layer. These two components were converted into hourly time steps using precipi, which corresponding to the hourly gross precipitation during the snow-covered period. Otherwise, precipi was used directly for the hydrological simulations because the hydrological model used in this study was calibrated using observed precipitation data before it was intercepted by the vegetation surface. evpsl and trnsl represented the amount of daily evaporation and transpiration from the soil layer. Both of these components were converted into hourly averaged values for the hydrological simulations. The evapotranspiration ratio was restricted according to the soil water content. The detailed procedures for estimating actual evapotranspiration loss were summarized by Sato et al. (2008).

\subsection{Hydrologic Impact Assessment}

We first investigated the performance of the distributed hydrological model by comparing the simulation results with observational data. Parameter calibration was performed to achieve reasonable reproduction of observed annual average river discharge at reference points in each river basin. Three statistical measures

$$
\begin{aligned}
& T W B E=\frac{\left[\sum Q_{c a l}-\sum Q_{o b s}\right]}{\sum Q_{o b s}} \times 100(\%) \\
& R M S E=\sqrt{\frac{\sum\left(Q_{c a l}-Q_{o b s}\right)^{2}}{n}}
\end{aligned}
$$

and

$$
E n=1-\frac{\sum\left(Q_{o b s}-Q_{c a l}\right)^{2}}{\sum\left(Q_{o b s}-Q_{a v e}\right)^{2}}
$$

were used to assess the performance. TWBE is the total water balance error (Fukushima 1988). RMSE (root mean-squared error) detects the degree of variance. En is the Nash-Sutcliffe coefficient value (Nash and Sutcliffe 1970). It was also used to assess the predictive performance of the hydrological model. $Q_{o b s}$ and $Q_{c a l}$ are the observed and calculated dis- charges for a specific month, $Q_{\text {ave }}$ is the average discharge, and $n$ is the number of data points. Although observed river discharge data were available in at least daily intervals, the calibration was performed based on the monthly averaged data. The hydrological model used in this study did not consider the influence of reservoir operations, which strongly impact daily river discharge. However, the influence of flood control and release operations on river discharge was assumed to be diluted if the data were averaged on a monthly basis because the storage capacity of the major reservoirs is limited and most flood events do not continue for long in the small river basins of Japan. Thus, to mitigate the influence of these anthropogenic factors, we focused on the monthly river discharges in our analysis.

Next, the bias between the AGCM output and the observed data was evaluated. Then, the snowmelt and evapotranspiration data estimated by the Soil Vegetation Atmosphere Transfer (SVAT) heat-balance model were also compared with the AGCM output. In this study, we used AGCM data without bias correction as the input variables for the distributed hydrological model. This was done because there is no guarantee that the bias correction obtained from the current climate experiment data and observed data is applicable to future data (Tachikawa et al. 2009). Finally, the impact of climate change on river discharge was investigated by comparing the results of the hydrological simulations based on the present and future climate conditions.

\section{STUDY AREA AND OBSERVED DATA}

Figure 2 shows the location of the major river basins in Japan selected for the study. The channel network and reference points of river discharge in each river basin are also indicated in the figure. The Ishikari, Mogami, and Agano river basins located in northern Japan were selected to represent the snow-dominated region. The Tone, Kiso, Nagara, and Yodo river basins located in central Japan were selected to represent the densely populated region. This region includes megacities such as Tokyo (capital of Japan), Nagoya, and Osaka. The Yoshino and Chikugo river basins, located in south-western Japan, were selected to represent the warm, humid region. Detailed information on each river basin is summarized in Table 2.

Surface meteorological datasets such as precipitation, air temperature, wind speed, and sunshine duration were obtained from about 1300 Automated Meteorological Data Acquisition System (AMeDAS) sites. AMeDAS is a high-resolution surface observation network developed by the JMA since 1974. The stations are located at average intervals of $17 \mathrm{~km}$ throughout Japan. All data are observed automatically every 10 minutes. Atmospheric and vapour pressure data are obtained from 155 in situ weather stations. At manned stations, the cloud cover, cloud heights, weather, types of precipitation, types of clouds, visibility, 
and humidity are also recorded. Most observation sites are distributed across Japan at intervals of less than $150 \mathrm{~km}$ on average.

To validate the runoff simulation, observed river discharge data were obtained from the Water Information System managed by the Ministry of Land, Infrastructure and
Transport (MILT), Japan (online data). Daily average river discharge data are available from the 1960s for most major river basins in Japan. Furthermore, long-term daily average river discharge datasets at reference points in major river basins were also obtained from the Japan River Association (offline data).

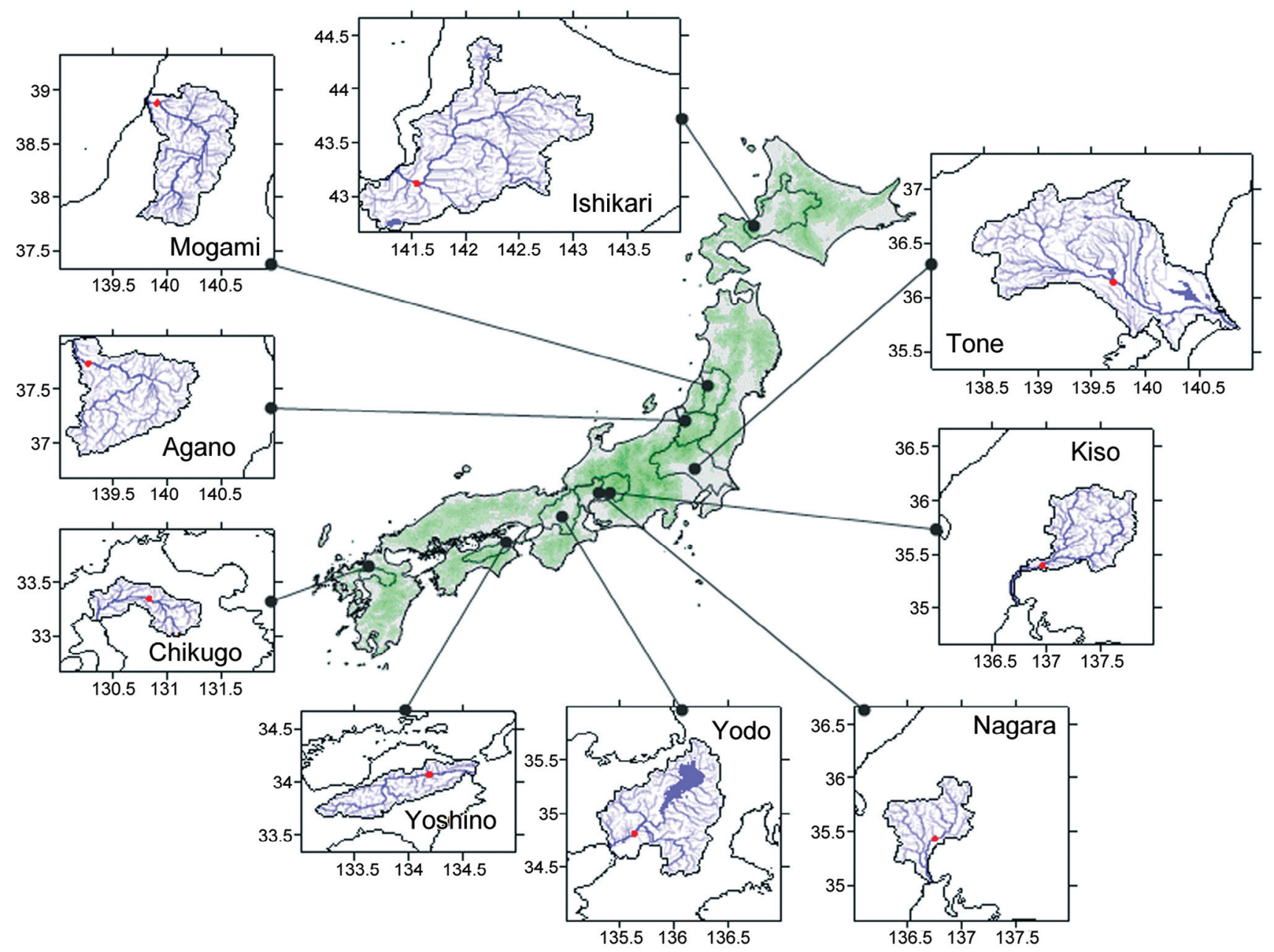

Fig. 2. Location and channel network of major river basins in Japan selected as study area.

Table 2. Characteristics of each river basin and hydrological station.

\begin{tabular}{|c|c|c|c|c|c|c|}
\hline River basin & Region & Total Area $\left(\mathbf{k m}^{2}\right)$ & Hydrological station & Longitude $\left({ }^{\circ} \mathbf{E}\right)$ & Latitude $\left({ }^{\circ} \mathbf{N}\right)$ & Drainage Area $\left(\mathbf{k m}^{2}\right)$ \\
\hline Ishikari & Hokkaido & 14330 & Ishikari ohashi & 141.5 & 43.1 & 12697 \\
\hline Mogami & Tohoku & 7040 & Sagoshi & 139.9 & 38.9 & 6497 \\
\hline Agano & Hokuriku & 7710 & Maoroshi & 139.3 & 37.7 & 6997 \\
\hline Tone & Kanto & 16840 & Kurihashi & 139.7 & 36.1 & 8588 \\
\hline Kiso & Chubu & 5275 & Inuyama & 137.0 & 35.4 & 4684 \\
\hline Nagara & Chubu & 1985 & Chusetsu & 136.8 & 35.4 & 1607 \\
\hline Yodo & Kinki & 8240 & Hirakata & 135.6 & 34.8 & 7281 \\
\hline Yoshino & Shikoku & 3750 & Iwazu & 134.2 & 34.1 & 2740 \\
\hline Chikugo & Kyushu & 2863 & Arase & 130.8 & 33.3 & 1440 \\
\hline
\end{tabular}




\section{RESULTS AND DISCUSSION}

\subsection{Performance of the Hydrological Model}

The calibration of the hydrological model mainly relied on a visual comparison (Fig. 3) of the calculated and observed river discharges over 20 years (1980 - 1999). Tables 3 and 4 summarize the results of the calibration. According to the TWBE, the model could reproduce the observed river discharge within approximately $3 \%$ for most river basins by parameter calibration. The overestimation in the Ishikari River basin $(+10.8 \%)$ might have been due to an overestimation of snowfall in the winter season. However, it was difficult to calibrate the amount of snowfall due to the lack of available data for validation. Therefore, we could not improve the performance in the Ishikari River basin further. On the other hand, $E n$ was reasonable for all river basins $(>0.51)$. As shown in Fig. 4, the seasonal variation in river discharges was closely reproduced by the hydrological model. Thus, we concluded that the model was appropriate for assessing the impact of climate change on river discharge.
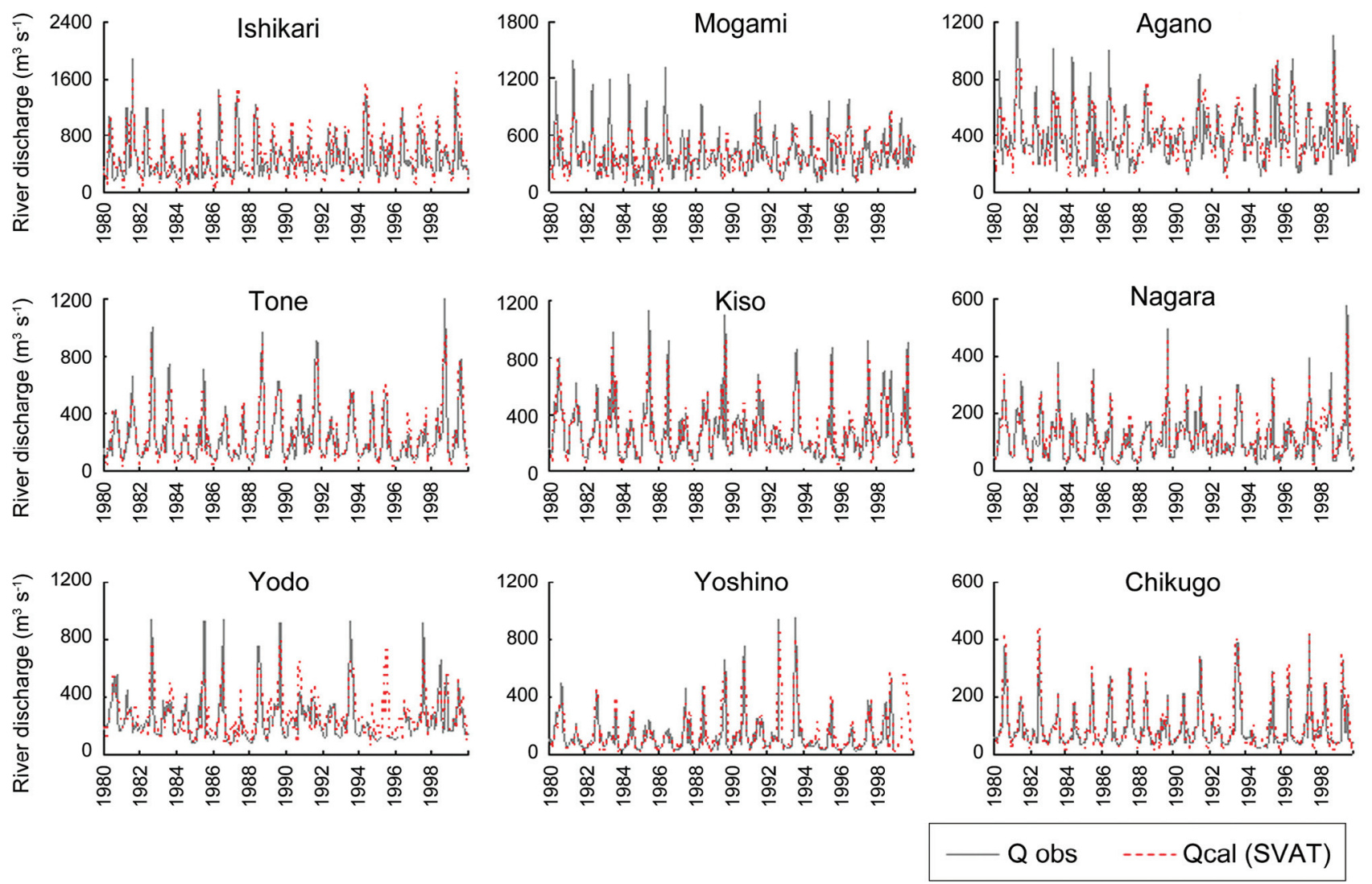

Fig. 3. Performance of the hydrological model for monthly river discharge of each river basin.

Table 3. Performance of the hydrological model.

\begin{tabular}{clccccc}
\hline River basin & Hydrological station & Observed $\left(\mathbf{m}^{\mathbf{3}} \mathbf{s}^{-1}\right)$ & Calculated $\left(\mathbf{m}^{3} \mathbf{s}^{-1}\right)$ & TWBE $(\%)$ & RMSE & En \\
\hline Ishikari & Ishikari ohashi & 457.0 & 506.6 & 10.8 & 179.6 & 0.63 \\
Mogami & Sagoshi & 367.6 & 388.5 & -2.3 & 131.6 & 0.67 \\
Agano & Maoroshi & 390.6 & 397.7 & 1.8 & 138.4 & 0.51 \\
Tone & Kurihashi & 234.4 & 227.7 & -2.8 & 54.0 & 0.89 \\
Kiso & Inuyama & 280.7 & 271.7 & -3.2 & 52.2 & 0.93 \\
Nagara & Chusetsu & 111.6 & 111.0 & -0.4 & 28.0 & 0.89 \\
Yodo & Hirakata & 246.3 & 249.4 & 1.2 & 107.6 & 0.60 \\
Yoshino & Iwazu & 127.6 & 128.2 & 0.5 & 73.7 & 0.73 \\
Chikugo & Arase & 85.3 & 84.3 & -1.1 & 18.1 & 0.95 \\
\hline
\end{tabular}


Table 4. Calibrated parameters for hydrological model.

\begin{tabular}{cccclll}
\hline River basin & Soil depth $(\mathbf{m})$ & $\mathbf{k 1}(\mathbf{1} / \mathbf{d})$ & $\mathbf{k 2}(\mathbf{1} / \mathbf{d})$ & $\mathbf{k 3}(\mathbf{1} / \mathbf{d})$ & $\mathbf{C 1}(\mathbf{m})$ & $\mathbf{C 2}(\mathbf{m})$ \\
\hline Ishikari & 0.2 & 0.075 & 0.4 & 0.01 & 0.005 & 0.001 \\
Mogami & 0.2 & 0.25 & 0.4 & 0.025 & 0.005 & 0.0005 \\
Agano & 0.4 & 0.3 & 0.4 & 0.03 & 0.005 & 0.0005 \\
Tone & 0.4 & 0.1 & 0.4 & 0.01 & 0.02 & 0.002 \\
Kiso & 0.075 & 0.2 & 0.4 & 0.05 & 0.004 & 0.0008 \\
Nagara & 0.045 & 0.16 & 0.4 & 0.06 & 0.0045 & 0.0005 \\
Yodo & 0.4 & 0.05 & 0.4 & 0.01 & 0.03 & 0.003 \\
Yoshino & 0.1 & 0.075 & 0.4 & 0.0075 & 0.005 & 0.0005 \\
Chikugo & 0.1 & 0.125 & 0.4 & 0.04 & 0.01 & 0.001 \\
\hline
\end{tabular}

Note: $k 1$ : horizontal runoff coefficient for upper soil layer; $k$ : infiltration ration from upper soil layer to lower soil layer; k3: horizontal runoff coefficient for lower soil layer; C1: Canopy interception storage capacity for upper stories; C2: Canopy interception storage capacity for lower stories.
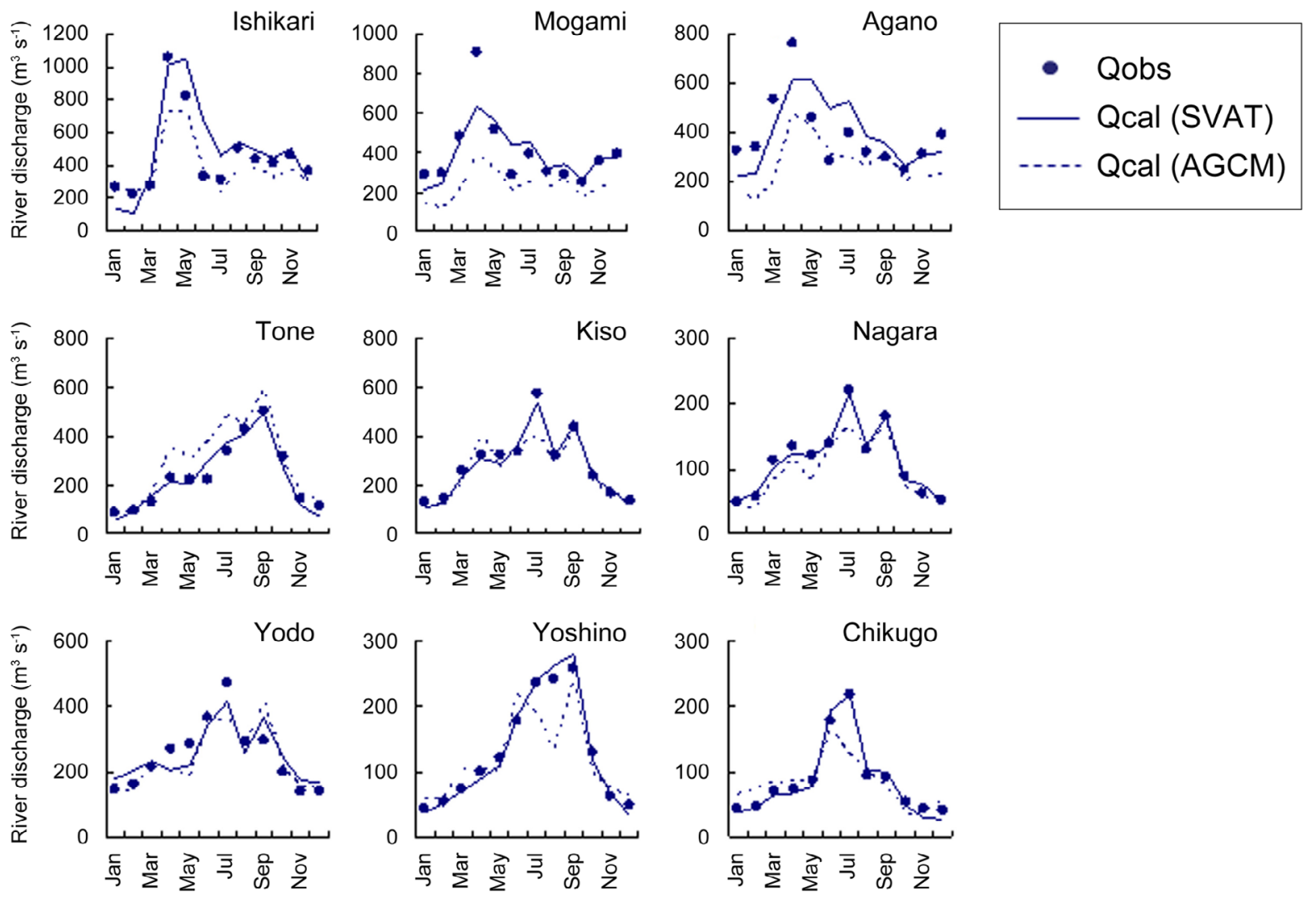

Fig. 4. Comparisons between AGCM output and observed in monthly precipitation of each river basin.

\subsection{Reproduction of the Present Climate by the AGCM}

Table 5 summarizes the performance of the MRIAGCM3.2S under present climate conditions (1980 - 1999). The values indicate the difference between AGCM output and observed data. The AGCM reproduced seasonal changes in air temperature almost perfectly, with biases of less than $0.8^{\circ} \mathrm{C}$. Annual precipitation was reproduced to within $\pm 10 \sim 20 \%$ relative errors, except for over the Tone $(+34 \%)$ river basins (Fig. 5). These results demonstrate that the MRI-AGCM closely reproduced the regional climate in each river basin.

The large differences in the amount of snowmelt between the AGCM and SVAT were due mainly to differences in the model structures. However, the difference in the southern regions is not so important for hydrological simu- 
Table 5. Calibrated parameters for hydrological model.

\begin{tabular}{|c|c|c|c|c|c|c|c|c|c|c|}
\hline & & Ishikari & Mogami & Agano & Tone & Kiso & Nagara & Yodo & Yoshino & Chikugo \\
\hline \multirow{4}{*}{ Air temperature $\left({ }^{\circ} \mathrm{C}\right)$} & Observed & 4.8 & 8.8 & 8.3 & 11.5 & 9.1 & 11.9 & 13.0 & 11.8 & 13.4 \\
\hline & $\mathrm{AGCM}$ & 4.6 & 8.5 & 8.0 & 10.7 & 8.3 & 11.0 & 12.3 & 11.3 & 12.7 \\
\hline & Diff. & -0.2 & -0.3 & -0.2 & -0.8 & -0.7 & -0.8 & -0.7 & -0.5 & -0.7 \\
\hline & C.C. & 1.00 & 1.00 & 1.00 & 1.00 & 1.00 & 1.00 & 1.00 & 1.00 & 1.00 \\
\hline \multirow{4}{*}{ Precipitation $(\mathrm{mm})$} & Observed & 1305 & 1924 & 1851 & 1397 & 2308 & 2632 & 1735 & 2082 & 2238 \\
\hline & AGCM & 1410 & 1889 & 2184 & 1879 & 2383 & 2711 & 1852 & 2259 & 2195 \\
\hline & R.E. & 1.08 & 0.98 & 1.18 & 1.34 & 1.03 & 1.03 & 1.07 & 1.08 & 0.98 \\
\hline & C.C. & 0.94 & 0.87 & 0.91 & 0.97 & 0.97 & 0.95 & 0.97 & 0.91 & 0.95 \\
\hline \multirow{4}{*}{ Snowmelt (mm) } & SVAT & 858 & 1032 & 1113 & 128 & 291 & 305 & 131 & 105 & 68 \\
\hline & AGCM & 493 & 610 & 767 & 219 & 425 & 336 & 66 & 93 & 90 \\
\hline & R.E. & 0.57 & 0.59 & 0.69 & 1.71 & 1.46 & 1.10 & 0.51 & 0.89 & 1.32 \\
\hline & C.C. & 0.97 & 0.96 & 0.96 & 0.66 & 0.83 & 0.95 & 0.99 & 0.99 & 0.99 \\
\hline \multirow{4}{*}{ Evapotranspiration (mm) } & SVAT & 356 & 402 & 394 & 703 & 614 & 692 & 690 & 771 & 734 \\
\hline & AGCM & 406 & 489 & 482 & 620 & 544 & 611 & 678 & 593 & 648 \\
\hline & R.E. & 1.14 & 1.21 & 1.22 & 0.88 & 0.89 & 0.88 & 0.98 & 0.77 & 0.88 \\
\hline & C.C. & 0.97 & 0.97 & 0.96 & 0.82 & 0.96 & 0.95 & 0.96 & 0.92 & 0.96 \\
\hline
\end{tabular}

Note: Diff: Difference between AGCM output and Observed data (=AGCM data-Observed data); R.E.: Relative Error; C.C.: Correlation Coefficient.

lations because the influence of snowmelt on river discharge is relatively small in those areas compared to the northern snow-dominated regions.

In the case of evapotranspiration, the difference between the AGCM and SVAT was relatively small compared to the difference in snowmelt. However, the AGCM output showed larger values in the north than in the south. The higher evapotranspiration ratios were mainly induced by the larger latent heat flux on water surfaces than that on ice surfaces due to an underestimation of snowfall. On the other hand, lower evapotranspiration ratios in the AGCM might have been caused by differences in the models. Namely, the potential evaporation calculated by the SVAT model tended to be larger than that calculated by the AGCM (SiB). However, these differences would not have a large influence on the river discharges.

Figure 4 also shows the monthly average river discharge calculated by the hydrological model using the AGCM output. The smaller river discharge by the AGCM in the northern part of Japan (Ishikari, Moami, and Agano river basins) was mainly due to the underestimation of snowmelt in the AGCM (see Table 5). Comparing the results with Fig. 5, it can be seen that the difference in river discharge in the Tone river basin was strongly influenced by the difference in precipitation. These results suggest that it is important to select a climate model that accurately reproduces precipitation and snowmelt to estimate river discharge more accurately. Dynamic downscaling using a more precise regional climate model (i.e., a non-hydrostatic model) with the AGCM as a boundary condition would be one reasonable solution to this problem. However, such data are available only for specific regions and events due to computational limitations. Bias correction is another way to improve model reproducibil-

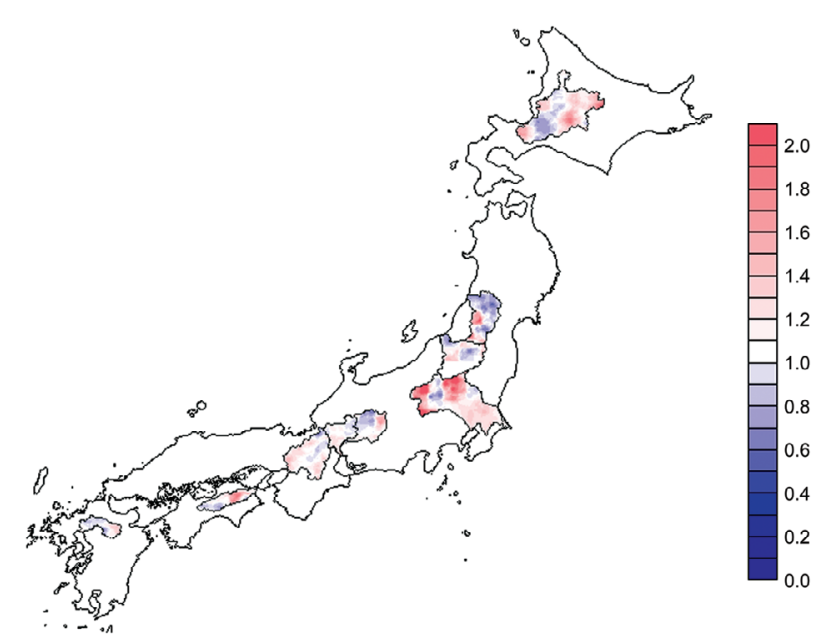

Fig. 5. Bias (ratio) between AGCM output and observed in annual precipitation of each river basin (= AGCM/Observed).

ity. However, there is no guarantee that bias correction for current climate data is applicable to future data. Therefore, we used the AGCM data directly for the future hydrological simulation.

\subsection{Future Hydrological Variables Projected by the MRI-AGCM}

Figure 6 indicates the relative change of calculated annual average river discharge between present (1980 - 1999) and future (2080 - 2099) climate conditions using AGCM output. The annual river discharge of each river basin will increase about 1 to $9 \%$ relative to the present flow at the reference point. The spatial differences of relative change in 
river discharge were also detected by the distributed hydrological simulation. Comparing the result with Fig. 7, we can see that regional differences of river discharge are strongly influenced by the difference in precipitation. Therefore, a combination with the distributed hydrological model and



Fig. 6. Relative change of calculated annual average river discharge using AGCM output between present and future climate condition (= Future/Present). super-high-resolution climate model is necessary for the impact assessment of climate change in a regional scale.

Figure 8 shows the difference in monthly river discharge between present and future climate conditions using the AGCM output. The relative changes between these

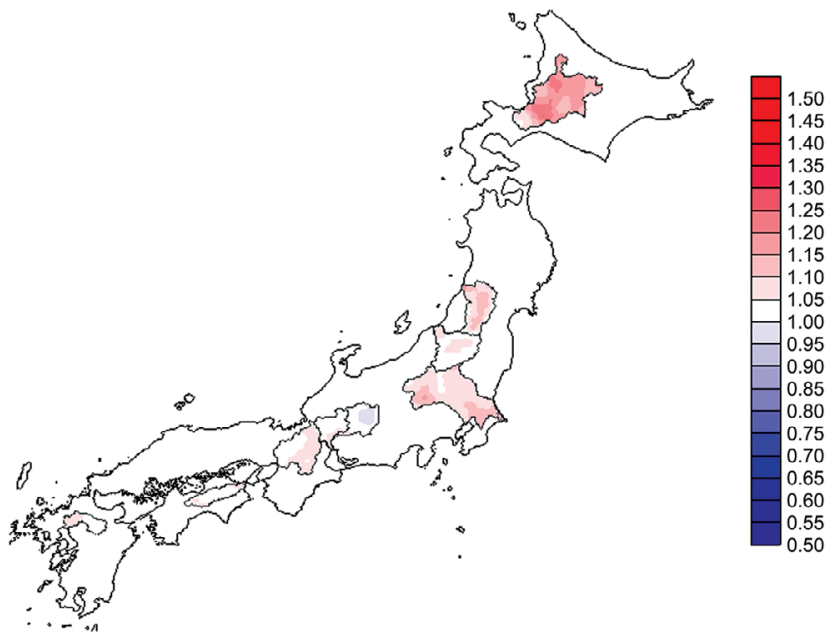

Fig. 7. Relative change of annual precipitation projected by AGCM between present and future climate condition (= Future/Present).
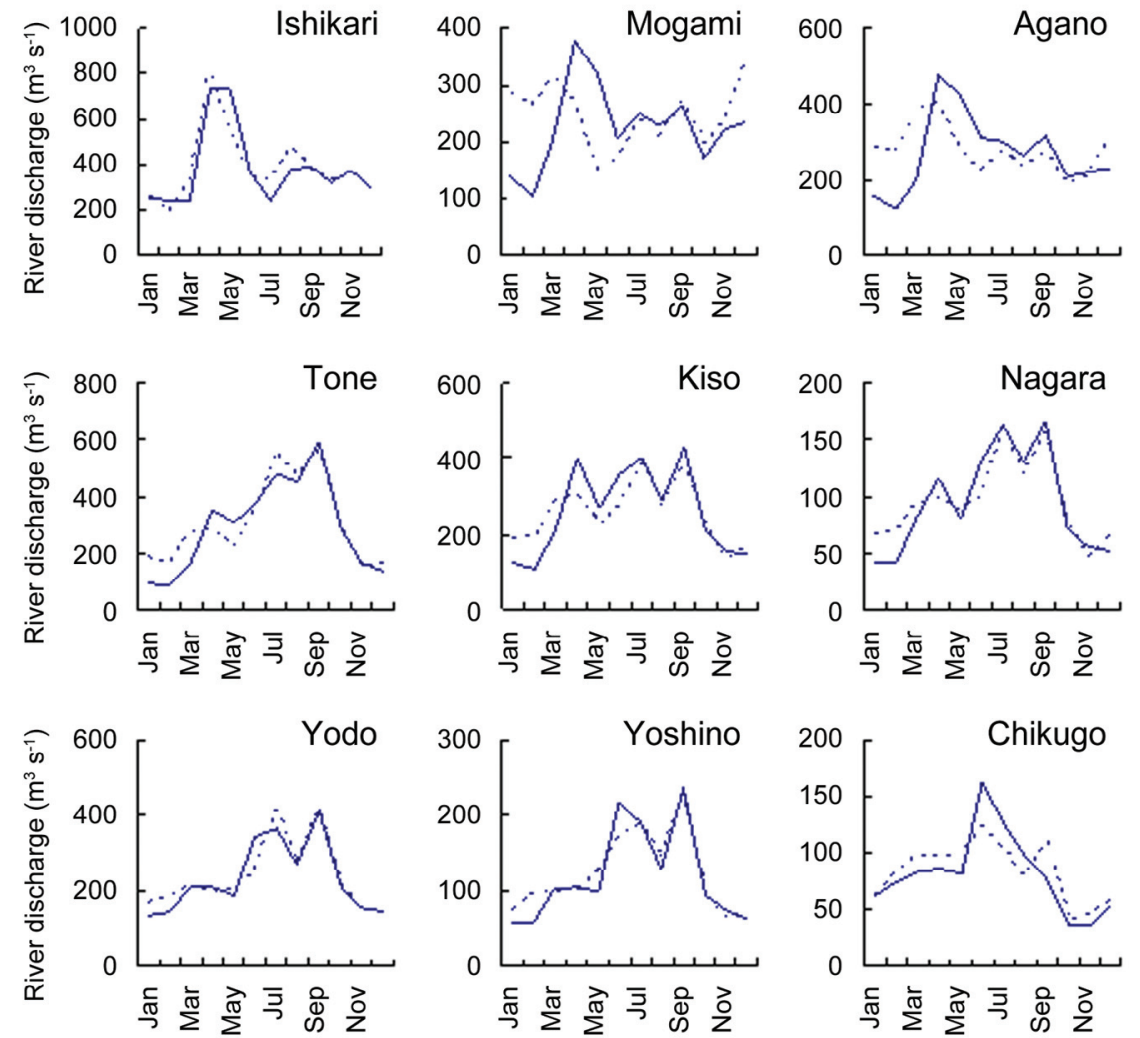

Fig. 8. Comparisons of calculated monthly average river discharge using AGCM output between present and future climate condition at reference point of each river basin. 
two periods for each river basin are summarized in Table 6. Shaded values in the table indicate that the change was statistically significant according to the t-test with a $95 \%$ level of confidence. Our results indicate that river discharge will increase in winter (December to March) and decrease in early spring (April to June) in most river basins in Japan. In particular, the river discharge was estimated to increase by more than $200 \%$ in February and then decrease to approximately $50-60 \%$ in May relative to the present flow in the Mogami and Agano river basins located in the Tohoku and Hokuriku regions, respectively. The lower reaches of the Mogami and Agano river basins encompass major rice production areas, including the Shonai Plain in Yamagata Prefecture and the Echigo Plain in Niigata Prefecture. Significant changes in the monthly average river discharges of these regions will considerably influence the regional economies and water resources management.
Figure 9 presents the changes in air temperature, precipitation, rainfall, snowmelt, and evapotranspiration projected by the AGCM between present and future climate conditions. These results suggest that river discharge will be influenced by increases in rainfall and decreases in snowmelt with higher air temperatures, even if the total precipitation does not change significantly. The contribution of the increase in evapotranspiration is almost the same for each river basin and was assumed to have relatively small influence compared to other variables. Despite the large temperature rises projected in the Ishikari River basin, the amounts of snowmelt and monthly river discharge did not change significantly. This could be explained by the change in monthly average air temperature. Figure 10 shows the monthly change in air temperature from present to future climate conditions. We found that the monthly average air temperature would not drop to less than $0^{\circ} \mathrm{C}$ in the future

Table 6. Relative change in river discharge between present and future climate conditions.

\begin{tabular}{l|cccccccccc}
\hline & Ishikari & Mogami & Agano & Tone & Kiso & Nagara & Yodo & Yoshino & Chikugo \\
\hline Average & 1.05 & 1.07 & 1.04 & 1.09 & 1.01 & 1.04 & 1.05 & 1.05 & 1.04 \\
January & 1.04 & 2.05 & 1.82 & 2.01 & 1.52 & 1.58 & 1.23 & 1.29 & 1.00 \\
February & 0.79 & 2.55 & 2.18 & 1.85 & 1.79 & 1.74 & 1.28 & 1.67 & 1.11 \\
March & 1.33 & 1.55 & 1.96 & 1.76 & 1.39 & 1.15 & 1.07 & 0.97 & 1.15 \\
April & 1.09 & 0.71 & 0.85 & 0.81 & 0.77 & 0.84 & 0.93 & 0.92 & 1.12 \\
May & 0.73 & 0.46 & 0.65 & 0.72 & 0.83 & 1.07 & 1.08 & 1.27 & 1.20 \\
June & 0.95 & 0.83 & 0.73 & 0.92 & 0.77 & 0.77 & 0.73 & 0.79 & 0.75 \\
July & 1.41 & 0.96 & 0.92 & 1.15 & 0.98 & 0.99 & 1.15 & 1.00 & 0.82 \\
August & 1.27 & 0.93 & 0.91 & 1.05 & 0.96 & 0.92 & 1.01 & 1.09 & 0.81 \\
September & 0.96 & 1.01 & 0.86 & 0.95 & 0.89 & 0.96 & 1.02 & 0.96 & 1.44 \\
October & 1.01 & 1.13 & 0.89 & 0.98 & 1.03 & 1.07 & 1.04 & 0.98 & 1.14 \\
November & 0.90 & 1.06 & 0.94 & 0.91 & 0.88 & 0.85 & 0.94 & 0.87 & 1.25 \\
December & 1.14 & 1.49 & 1.37 & 1.19 & 1.15 & 1.24 & 1.01 & 1.11 & 1.11 \\
\hline
\end{tabular}

Note: Shading indicates statistical significance (95\% confidence level).
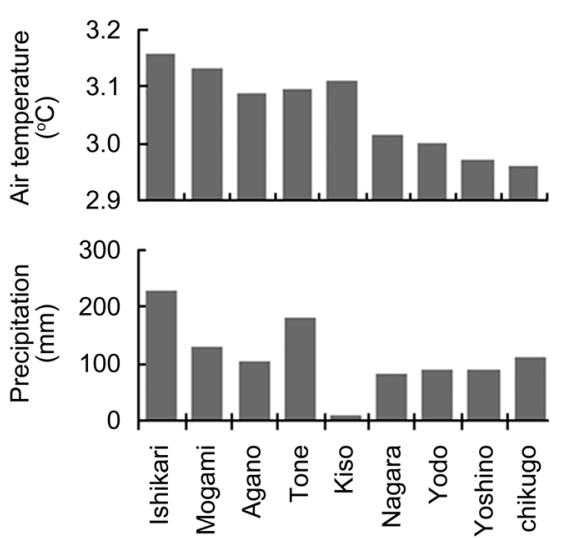
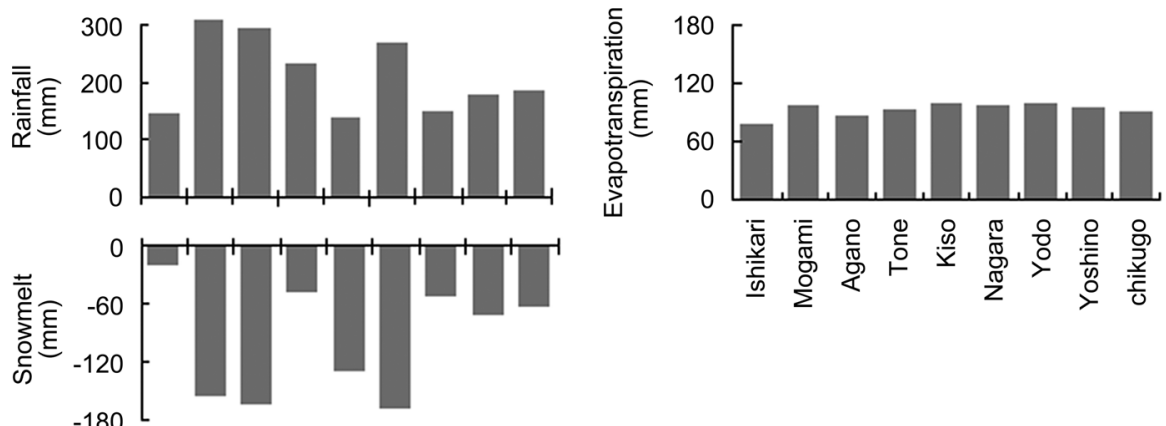

Fig. 9. Change in air temperature, precipitation, rainfall, snowmelt, and evapotranspiration projected by AGCM between present and future climate condition (= Future - Present). 

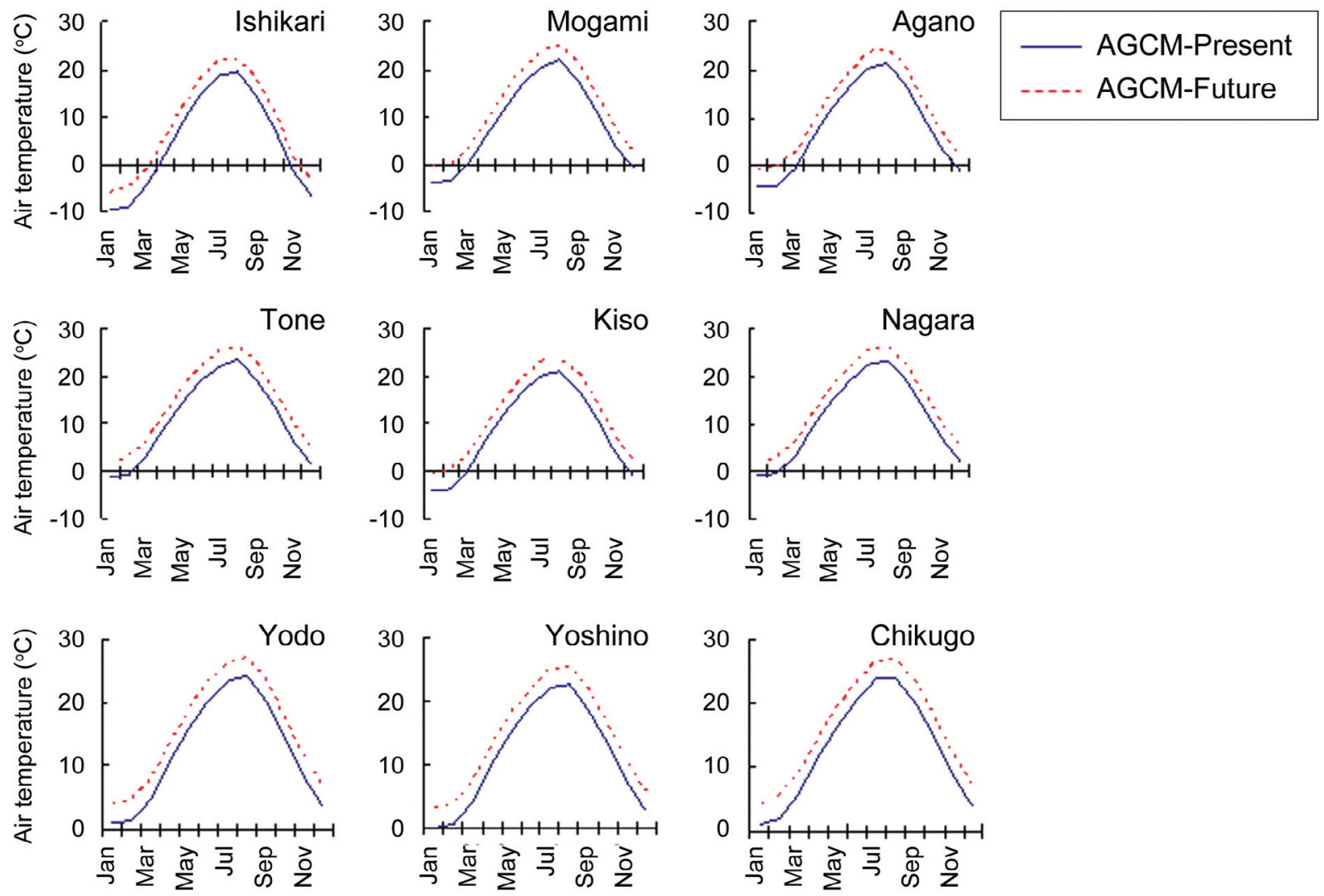

Fig. 10. Comparisons of calculated monthly average air temperature projected by AGCM output between present and future climate condition at reference point of each river basin.

climate in most river basins. In the case of the Ishikari River basin, however, there were still days below $0^{\circ} \mathrm{C}$ in the winter season in the future climate. This would restrict the conversion of snowfall to rainfall in the winter season. These hydrological responses under future climate conditions are almost consistent with the result of Tachikawa et al. (2009) for the Mogami and Yoshino river basins using previous versions of the AGCM (MRI-AGCM3.1S).

Finally, we investigated the change in hydrological variables between present and future climate conditions to clarify their contributions to the monthly water balance in each river basin (Fig. 11). As discussed for Fig. 9, we confirmed that the increase in winter flow and decrease in spring flow were induced by the increase of winter precipitation and subsequent decrease in snowmelt. The change in river discharge in summer was not statistically significant and can be explained by changes in rainfall and evapotranspiration. These results suggest that studying the long-term water balance is necessary to clarify the hydrological impact of climate change.

\section{CONCLUSIONS}

To evaluate the impact of climate change on river discharges in Japan, a distributed hydrological simulation was performed using the latest version of a super-highresolution AGCM (MRI-AGCM3.2S) with a horizontal resolution of about $20 \mathrm{~km}$ to obtain the input meteorological forcing data. Using a pre-calibrated hydrological model made the AGCM output clearer for specific river basins. The AGCM accurately reproduced hydrology under present-day climate conditions on regional scales without any bias correction. However, in the case of snow-dominated regions, the river discharge was underestimated by the AGCM, mainly due to the scarcity of snow. In future projections based on the SRES A1B scenario, we found that even if the amount of precipitation does not change much, river discharge will change significantly due to increases in rainfall and decreases in snowmelt as the air temperature rises. The river discharge in winter will increase by more than $200 \%$ in February and then decrease approximately $50-60 \%$ in May in the Tohoku and Hokuriku regions. We also found that the impact of climate change in the Hokkaido region will not be so significant, as the monthly air temperature in winter will still remain less than $0^{\circ} \mathrm{C}$, even in a warmer climate. Finally, the water balance analysis revealed that the increase in winter flow and decrease in spring flow were induced by 

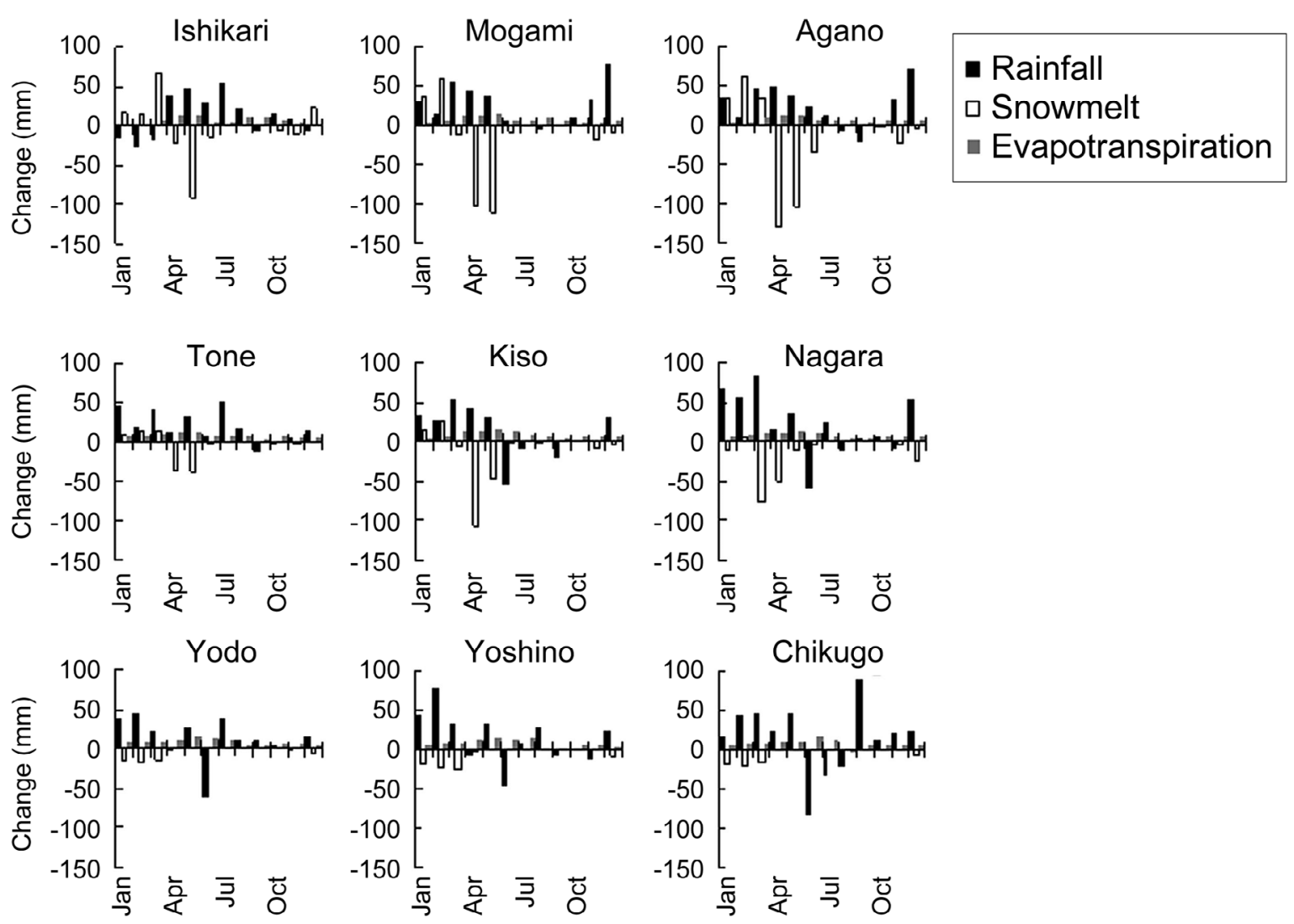

Fig. 11. Change in monthly rainfall, snowmelt, and evapotranspiration projected by AGCM between present and future climate condition (= Future - Present).

the increase of winter precipitation and the subsequent decrease in snowmelt.

Acknowledgements This work was performed under the framework of the "Projection of changes in extremes in the future with very high-resolution atmospheric models" project supported by the KAKUSHIN Program and funded by the Ministry of Education, Culture, Sports, Science and Technology (MEXT), Japan. The calculations were performed on the Earth Simulator.

\section{REFERENCES}

Barnett, T. P., J. C. Adam, and D. P. Lettenmaier, 2005: Potential impacts of a warming climate on water availability in snow-dominated regions. Nature, 438, 303309, doi: 10.1038/nature04141. [Link]

Fukuda, M. and T. Ishizaki, 1980: A simulation model for frost penetration beneath the ground on the basis of equilibrium surface temperatures. J. Jpn. Soc. Snow Ice, 42, 71-80. (in Japanese)

Fukushima, Y., 1988: A model of river flow forecasting for a small forested mountain catchment. Hydrol.Process., 2, 167-185, doi: 10.1002/hyp.3360020207. [Link]
Hara, M., T. Yoshikane, H. Kawase, and F. Kimura, 2008: Estimation of the impact of global warming on snow depth in Japan by the Pseudo-Global-Warming method. Hydrol. Res. Lett., 2, 61-64, doi: 10.3178/hrl.2.61. [Link]

Hirabayashi, Y., S. Kanae, S. Emori, T. Oki, and M. Kimoto, 2008: Global projections of changing risks of floods and droughts in a changing climate. Hydrol. Sci.J., 53, 754-772, doi: 10.1623/hysj.53.4.754. [Link]

Kitoh, A., A. Yatagai, and P. Alpert, 2008: First super-highresolution model projection that the ancient "Fertile Crescent" will disappear in this century. Hydrol. Res. Lett., 2, 1-4, doi: 10.3178/hrl.2.1. [Link]

Kitoh, A., T. Ose, K. Kurihara, S. Kusunoki, M. Sugi, and KAKUSHIN Team-3 Modeling Group, 2009: Projection of changes in future weather extremes using superhigh-resolution global and regional atmospheric models in the KAKUSHIN program: Results of preliminary experiments. Hydrol. Res. Lett., 3, 49-53, doi: 10.3178/ hrl.3.49. [Link]

Kojiri, T. 2006: Hydrological river basin assessment model (Hydro-BEAM). In: Singh, V. P. and D. K. Frevent, (Eds.), Watershed models. Taylor \& Francis, CRC Press, Florida, 613-626. 
Kondo, J. 1994: Meteorology of the Water Environment. Asakura, Tokyo, 348 pp. (in Japanese)

Kondo, J. and T. Yamazaki, 1990: A prediction model for snowmelt, snow surface temperature and freezing depth using a heat balance method. J. Appl. Meteorol. Climatol., 29, 375-384, doi: 10.1175/1520-0450(1990)029 $<0375$ :APMFSS $>2.0 . \mathrm{CO} ; 2$. [Link]

Kondo, J. and J. Xu, 1997: Potential evaporation and climatological wetness index. J. Meteorol. Soc. Jpn., 44, 875-883. (in Japanese)

Kusunoki, S., R. Mizuta, and M. Matsueda, 2011: Future changes in the East Asian rain band projected by global atmospheric models with $20-\mathrm{km}$ and $60-\mathrm{km}$ grid size. Climate Dyn., 37, 2481-2493, doi: 10.1007/s00382-011 -1000-x. [Link]

Ma, X., T. Yasunari, T. Ohata, L. Natsagdorj, G. Davaa, and D. Oyunbaatar, 2003: Hydrological regime analysis of the Selenge River basin, Mongolia. Hydrol. Process., 17, 2929-2945, doi: 10.1002/hyp.1442. [Link]

Milly, P. C. D., R. T. Wetherald, K. A. Dunne, and T. L. Delworth, 2002: Increasing risk of great floods in a changing climate. Nature, 415, 514-517, doi: 10.1038/ 415514a. [Link]

Milly, P. C. D., K. A. Dunne, and A. V. Vecchia, 2005: Global pattern of trends in streamflow and water availability in a changing climate. Nature, 438, 347-350, doi: 10.1038/nature04312. [Link]

Mizuta, R., K. Oouchi, H. Yoshimura, A. Noda, K. Katayama, S. Yukimoto, M. Hosaka, S. Kusunoki, H. Kawai, and M. Nakawaga, 2006: 20-km-mesh global climate simulations using JMA-GSM model. J. Meteorol. Soc. Jpn., 84, 165-185, doi: 10.2151/jmsj.84.165. [Link]

Nakaegawa, T. and W. Vergara, 2010: First projection of climatological mean river discharges in the Magdalena River basin, Colombia, in a changing climate during the $21^{\text {st }}$ century. Hydrol. Res. Lett., 4, 50-54, doi: 10.3178/HRL.4.50. [Link]

Nash, J. E. and J. V. Sutcliffe, 1970: River flow forecast- ing through conceptual models part I - A discussion of principles. J. Hydrol., 10, 282-290, doi: 10.1016/00221694(70)90255-6. [Link]

Nohara, D., A. Kitoh, M. Hosaka, and T. Oki, 2006: Impact of climate change on river discharge projected by multimodel ensemble. J. Hydrolometeorol., 7, 1076-1089, doi: 10.1175/JHM531.1. [Link]

Ohizumi, M. and M. Hosaka, 2000: Land surface processes in appendix to progress report on numerical weather prediction. Jpn. Meteorol. Agency, 46, 48-66. (in Japanese)

Outcalt, S. I., C. Goodwin, G. Weller, and J. Brown, 1975: Computer simulation of the snowmelt and soil thermal regime at Barrow, Alaska. Water Resour. Res., 11, 709-715, doi: 10.1029/WR011i005p00709. [Link]

Qiu, J., 2008: China: The third pole. Nature, 454, 393-396, doi: 10.1038/454393a. [Link]

Sato, Y., X. Ma, J. Xu, M. Matsuoka, H. Zheng, C. Liu, and Y. Fukushima, 2008: Analysis of long-term water balance in the source area of the Yellow River basin. $H y$ drol. Process., 22, 1618-1629, doi: 10.1002/hyp.6730. [Link]

Tachikawa, Y., S. Takino, Y. Ichikawa, and M, Shiba, 2009: Study on the impact of climate change on river flow regimes in the Mogami and Yoshino River basins. Annu. J. Hydraul. Eng., 53, 475-480. (in Japanese)

Vörösmarty, C. J., P. Green, J. Salisbury, and R. B. Lammers, 2000: Global water resources: Vulnerability from climate change and population growth. Science, 289, 284-288, doi: 10.1126/science.289.5477.284. [Link]

Wada, K., M. Kawasaki, Y. Tomizawa, S. Kusunoki, and K. Kurihara, 2008: Study on the flood risk assessment of global warming by regional climate model and high resolution general circulation model. J. Jpn. Soc. Hydrol. Water Resour., 21, 12-22. (in Japanese)

Xu, J., S. Haginoya, K. Saito, and K. Motoya, 2005: Surface heat balance and pan evaporation trends in Eastern Asia in the period 1971-2000. Hydrol. Process., 19, 2161-2186, doi: 10.1002/hyp.5668. [Link] 